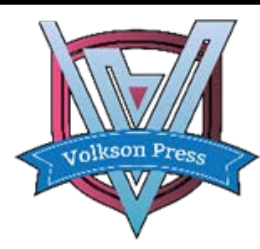

Contents List available at Volkson Press

Economics, Business and Management (EBMan)

DOI : http://doi.org/10.26480/wsebm.01.2017.26.27

\title{
THE FACTORS INFLUENCE NON-PERFORMING LOAN AND METHODS TO AMELIORATE NON-PERFORMING LOAN
}

\author{
Qiu Qianying \\ School of International Education, Wuhan University of Technology Luoshi Road, Wuhan, P. R. China, 430070 \\ *Corresponding Author E-mail: qiuqianying1996@qq.com
}

This is an open access article distributed under the Creative Commons Attribution License, which permits unrestricted use, distribution, and reproduction in any medium, provided the original work is properly cited.

\section{ARTICLE DETAILS}

\section{ARTICLE HISTORY:}

Received 27th December 2017

Accepted 29th December 2017

Available online 29th December 2017

\section{KEYWORDS:}

non-performing loan, economy system, bank

\begin{abstract}
Non-performing loan is an important factor when analyzing bank's performance and safety. At the late of last century, the amount of non-performing loan in China was very large, due to the reason that China need much money to develop and the government gave order to the commercial banks to give loan. This paper first analyzes the trend of non-performing loan and non-performing loan ratio from 2006 to 2015 in China's banks, and comes to the conclusion that the non-performing loan is mainly concentrated in great commercial banks and the non-performing loan ratio of foreign banks is the lowest among different kinds of commercial banks. The paper further analyzes the factors influencing non-performing loan from the respect of economic system, company, and the bank. The paper concludes with a recommendation of establishing and improving multi-tiered capital market, credit evaluation index system in China and credit risk evaluation system in the banks so as to address the issue of non-performing loan.
\end{abstract}

\section{INTRODUCTION}

Non-performing loan measures the loan which can't be paid in time, which restricts the development of banks and reflects the operational risk of banks. According to standard \& poor's, the amount of non-performing loan in China's bank was up to 200 billion dollars in 1996, and non-performing loan ratio was $22.8 \%$ at that time. Actually, it was higher than that of the banks in Southeast Asia before Southeast Asia financial crisis in 1997. Such a great amount of non-performing loan is rare in the world history. This led to great concern to Chinese government, so Chinese government took efficient methods in order to reduce the non-performing loan, which included selling non-performing loan to asset Management Corporation, asset securitization, etc. Thereafter, we saw that the no-performing loan fell in the majority of the banks in China. Reducing non-performing loan is of great importance in the development of an economy.

The ongoing investigation on the macro factors came up with similar result. A group researcher came up with the conclusion that non-performing loan ratio has negative relationship with GDP. Besides GDP, many researchers analyses the influence of other macro factors on non-performing loan. A researcher came to the conclusion that non-performing loan has positive relationship with consumer price index (CPI), producer price index (PPI), the amount of investment to real estate, total imports and exports and the interest rate for one-year loans, while it has negative relationship with GDP, total retail sales of consumer goods and housing sales area [1].

Most of researcher believed that asset price bubbles, the reform of macro economy system and the macroeconomic regulation and control do influence the non-performing loan [2]. A study focused on the China Merchants Bank and found that non-performing loan will increase when the economy shrinks [3]. As for the micro factors which influence the nonperforming loan, it also attacks many scholars interest. Some of researcher found out that the lack of clarity of property rights of enterprises and banks, the lack of dependence of the management system, the weak internal control of bank is the root cause of non-performing loan [4].

\section{2. LOANS}

As shown in table1.1 below, the non-performing loan balance of banking financial institutions went down from 2006 to 2009, and suddenly increased from 2009 till 2015 with a slight decline in 2010. The non-performing loan ratio of banking financial institutions fell from $7.5 \%$ in 2006 to $1.6 \%$ in 2009, after that it increased a little to $2.4 \%$ and then decreased below $2 \%$ until 2015.

When it comes to the total commercial banks, the non-performing loan balance declined from 2006 to 2011 and then went up to 12744.2 billion Yuan almost the same to that in 2006. However, the non-performing loan ratio of the total commercial bank had similar trend as that of the banking financial institutions [5].

As we can see, from 2006 to 2009, the non-performing loan balances of total commercial banks are mainly concentrated in the large commercial banks, and the ratio was up to $90 \%$ approximately [6]. From 2011, the nonperforming loan balance of other kinds of commercial banks finally increased, especially joint-equity commercial banks and rural commercial banks, which accounted for $19.9 \%$ and $14.6 \%$ selectively in 2015 . Unlike foreign banks, other commercial banks experienced high non-performing loan ratio which were up to about 6-8\% in 2006, and declined until 2010 to blow $2 \%$, and then maintain a relatively flat trend [7]. The non-performing loan ratio of rural commercial banks was at about 2\% from 2010 to 2015 . As for the foreign banks, they have kept a flat and low non-performing loan ratio.

Table 1: Non-performing loan and non-performing loan ratio 


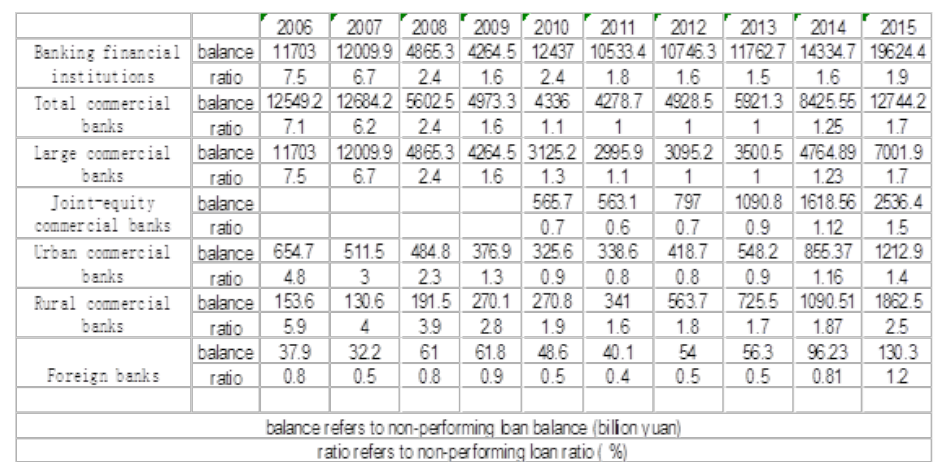

3. LOAN

\subsection{From the respect of Economic system}

Being a late starter of capital market, the way to finance was extremely limited in China for a long time. Companies depended on bank to finance heavily, so most of the loans were given out by banks [8]. The biggest problem in this was that companies had high debt ratio. As long as the companies faced challenge in earning, it will definitely affect their ability to pay back the loan then affect banks. Thus, the non-performing loan formed.

\section{2}

\section{From the respect of the company}

Some leaders lack leadership quality, which means the leader can't gather talents around the company nor make a rapid and accurate decision in the complex and changeable situation. Some leaders only think of themselves facing the interests instead of the companies, in which the company can't stay long. All this can cause the inability to refund.

Besides poor management, actually, many companies in China have poor credit, especially in the 1980s and 19990s [9]. Lack of regulation and lack of consciousness of credit, many enterprisers would like to repudiate a debt. According to the data, in recent years, contract disputes account for $92 \%$ in the economy disputes that court considered. Less than $70 \%$ of contract signed between enterprisers was executed at different levels. From the respect of the whole country, the amount of funds that made up the chain of debt was very large due to the lack of credit of companies. At the end, banks could not receive the loans which turn to be bad loan.

\subsection{From the respect of the bank}

In China, large commercial banks are backed by the government for a long time, believing the country credit, most of the people and enterprisers would tend to put their funds to them. Thus, a large scale of non-performing loan was occurred in the large commercial banks. Furthermore, the lack of diversity of main body of the property structure in large commercial banks and the heavy historical burden both led to great non-performing loan.

\section{4.}

\section{METHODS TO REDUCE NON-PERFORMING LOAN}

The government should accelerate the development of capital market, so the companies have more ways to finance. In nowadays, the structure of financing in China is still imbalance, for the reason that indirect financing is the main way to finance. According to the data, direct financing accounted for only $42.3 \%$ in 2012, while that of America accounted for $86 \%$ in the same period. Thus, the Chinese government should improve the multi-tiered capital market.

Besides multi-tiered capital market, the government should establish and improve credit evaluation index system, which includes companies pay back loans in time. Once the government collects the data, they are advised to do publicity in a regular time, which can strengthen the consensus of credit of companies. Also, corresponding incentive and punishment mechanism should be proper and strict.

For the bank, they should establish the credit risk evaluation system. Before decided to give loan to the companies, banks should do pre-loan credit investigation prudently. During the period of lending, banks can send some staffs to see whether the company is doing well and can give some suggestions. After calling in loan, bank should draw on past experiences, and summarize the feature lesson and experience in it.

\section{ACKNOWLEDGMENTS}

The author acknowledges the contribution of Brima Sesay and anonymous referees for valuable comments and suggestions.

\section{REFERENCES}

[1] Tian, L. 2014. The macro-economic stress test study of nonperforming loan ratio of commercial Banks in China after the subprime mortgage crisis. Yun Nan university of finance and economy.

[2] Xiaolong, C. 2016. The influence of macroeconomic factors on the banks' non-performing loan ratio research. southwestern university of finance and economics

[3] Rui, Y. 2016. The Influencing factors analysis on nonperforming loans ratio to take China Merchants Bank as an example. Southwestern university of finance and economics.

[4] Ningxin, C., Zilian, L. 2016. Study on the influencing factors of non-performing loan ratio of commercial Banks in China. Economic research.

[5] Fang, L. 2016. Analysis of the causes and solutions of nonperforming loans in commercial Banks. Financial point of view.

[6] Yu, S. 2003. Analysis of the Internal Mechanism of the Bad Load Generation in Chinese Commercial Banks. Ji Lin University.

[7] Dongyi, W. 2012. Internal Control Research about Listed Commercial Banks of China, Research Institute for Fiscal Science. Ministry of Finance, People's Republic of China.

[8] Hao, X. 2015. Economic growth, the non-performing loan ratio of Banks and quantitative easing. Financial theory and practice.

[9] Huachun, Y. 2004. The Statistic Research of Control the Risk of Commercial Bank’s NPL in Our Country. Hu Nan university. 